\title{
The Problem of Privacy in Capitalism and the Alternative Social Networking Site Diaspora*
}

\author{
Sebastian Sevignani
}

\author{
Unified Theory of Information Research Group (UTI), sebastian.sevignani@uti.at
}

\begin{abstract}
In this paper, I examine the alternative social networking site Diaspora* from a Marxist standpoint. The investigation focuses on privacy, and contributes to a better understanding of this issue within the context of capitalism in general. First, I describe Diaspora*'s way of production by pointing out its alternative character as part of the free software and copyleft movement. Second, dominant theories of privacy related to individual control, exclusion, and property are introduced. Third, the problem of privacy in capitalism is described wherein dominant concepts of privacy will be contextualised on behalf of a critical political economy analysis that refers to the Marxian concept of ideology critique, Marx's differentiation between a societal sphere of production and a societal sphere of circulation, and his analysis of capitalist fetishisms. Fourth, taking into account the problem of privacy in capitalism, the alternative potential of Diaspora* is evaluated. Finally, a brief outline of a Marxist theory of privacy is proposed.
\end{abstract}

Keywords: Social networking sites, privacy, private property, surveillance, Marx, ideology, fetishism, critical Internet studies, alternative media

Acknowledgement: The research presented in this article was conducted in the project "Social Networking Sites in the Surveillance Society" (http://www.sns3.uti.at), funded by the Austrian Science Fund (FWF): project number P 22445-G17. Project co-ordination: Prof. Christian Fuchs.

In 2010, four young New York university students were listening to a speech by law professor and free software foundation advocate, Eben Moglen, entitled: "Freedom in the Cloud: Software Freedom, Privacy, and Security for Web 2.0 and Cloud Computing" (2010). Moglen, also known as the author of the dotCommunist Manifesto (Moglen 2003), a document where he, inspired by Marx, propagates a contradiction between free information and multi-national capitalism in the age of the Internet, describes in his speech the surveillance-based heteronomy that users face within an Internet controlled by large corporate monopolists. Corporations, such as Facebook and Google, are able to dictate "take-it-or-leave-it" terms and provide users with a dubious but working privacythreatening deal: "I will give you free web hosting and some PHP [personal home page tools] doodads and you get spying for free all the time" (Moglen 2010). Moglen challenges the status quo by stressing that the situation need not be the way it currently is. Technological means that are currently available, he points out, provide us with a potential alternative to an Internet controlled by powerful centres. He calls upon his audience: "We're technologists, we should fix it [...]. You know every day that goes by there's more data we'll never get back. Every day that goes by there's more data inferences we can't undo. Every day that goes by we pile up more stuff in the hands of the people who got too much" (Moglen 2010).

The four students were inspired by Moglen's call to start developing an alternative social networking site (SNS), Diaspora*, that was soon and perhaps too soon celebrated as the potential Facebook-Killer. The euphoria comes, on the one hand, from Diaspora*'s quick success in fundraising. Via an Internet platform, they were able to raise 200,000 USD to get their project running. On the other hand, Facebook, the world's biggest SNS and second most frequented website, has faced several privacy problems as well as growing user discontent. By now, Diaspora* has been released to a broader public, it has ensured itself further funding and has built up an organizational structure, but the software is still in its alpha phase and remains a work in progress - at least in terms of its future and role in the struggle for a sustainable information society.

In the course of this paper, I describe Diaspora*'s way of production by pointing out its alternative character as part of the free software and copyleft movement. Second, dominant theories of privacy related to individual control, exclusion, and property are introduced. Third, the problem of privacy in capitalism is described wherein dominant concepts of privacy will be contextualised on behalf of a critical political economy analysis that refers to the Marxian concept of ideology critique, Marx's differentiation between a societal sphere of production and a societal sphere of circulation, and his analysis of capitalist fetishisms. Fourth, taking into account the problem of privacy in capi- 
talism, the alternative potential of Diaspora* is evaluated. Finally, a brief outline of a Marxist theory of privacy is proposed.

\section{The Alternative Social Networking Site Diaspora*}

Apart from Diaspora*'s early stage of development, it looks similar and provides features akin to those of well-known commercial SNSs. In terms of social privacy, i.e. privacy relative to other SNS users (Raynes-Goldie 2010), Diaspora* allows users to specifically assign to different groups various access opportunities in terms of their own activities on the SNS. Diaspora* can be described not only as an alternative to existing SNSs in terms of these elaborate settings for social privacy or in its funding through donations instead of advertising, but also particularly in the fact that the site is fundamentally different in its infrastructure and mode of production. This difference holds important alternative consequences for its users. In describing this alternative SNS, it is useful to distinguish between two levels. One is the code level; here, we are interested in how Diaspora*'s software is produced, what the means to produce SNS looks like, and in which social relations they are embedded. The other level is the user level; here, we are interested in the use value of Diaspora*, such as its ability to satisfy users' need for privacy. We will see that on Diaspora* the user level interacts with the code level in an important manner.

Diaspora* is a distributed SNS, which means that uploaded user data are not stored and managed centrally. Unlike Facebook and Google+, which process user data in huge server parks, Diaspora* consists of a potentially unlimited number of interoperating servers that are locally distributed and not controlled by a single organisation. Theoretically, it is possible for everyone to operate such a "pod". Therefore, the Diaspora* project should be seen in the context of initiatives that seek to empower users to run personal, self-controlled servers easily. For instance, the Freedom Box initiative describes itself as "a project that combines the computing power of a smart phone with your wireless router to create a network of personal servers to protect privacy during daily life [...]. The basic hardware and software components already exist. Our job is to assemble the right collection of social communication tools, distributed services, and intelligent routing in a package anyone can use to get the freedoms we all need right out of the box" (Freedom Box Foundation n.d.). Practically, however, there are a limited number of servers ${ }^{1}$, hence the social network is not yet distributed widely. Nevertheless, the principle behind Diaspora* is aimed at this direction: "Get started on a community pod and then move all of your social data to a pod you control. Diaspora*'s distributed design means that you will never have to sacrifice control of your data" (Diaspora* n.d.a). The effect of this structure is that "as soon as it becomes public that a company is exploiting the data of the users of its pod, they move away and the company is dead (in that sector). So the product shifts from you being the product to the software being the product" (Diaspora* 2012).

Chopra and Dexter (2006) describe the traditional capital strategy to make profit in the informational economy: capital is closing the source code and this means excluding others from this code on behalf of private property rights. "In this model then, the 'means of production' remain with the corporate owner of the software, because the worker is unable to modify the code" (Chopra and Dexter 2006, 8). Due to the specific quality of the means of production, however, the production of informational goods, such as software code, comes potentially in conflict with capital interest for the following reasons:

- Information is produced and diffused by networks,

- information is hard to control in terms of accessibility and ownership,

- and as information is intangible, it can easily be copied and owned by many, which consequently undermines individual private property (Fuchs 2009, 76f.; see also Benkler 2006, 60).

Marx argues that the "social relations between the producers, and the conditions under which they exchange their activities and share in the total act of production, will naturally vary according to the character of the means of production" (Marx 1849/2006, 28). The Diaspora* software is produced and developed according to a mode of production that can be called "peer-production" (Benkler 2006, Bauwens 2005), which is a way of producing goods and services that relies on selforganizing communities of individuals who come together to produce a shared and desired outcome. Instead of being exchanged, outcomes and inputs of the working process are shared. Goods and services in peer-production are therefore not commodities, because "only the products of mutually independent acts of labour, performed in isolation" can become commodities (Marx 1867/1976, 57).

\footnotetext{
${ }^{1}$ See list at http://podupti.me/
} 
In terms of forces and modes of production, Marx argues further that "at a certain stage of their development, the material forces of production in society come in conflict with the existing relations of production, or - what is but a legal expression for the same thing - with the property relations within which they had been at work before" (Marx 1859/1909, 12). The Diaspora* software, to which access is needed for users to set up their own pods, is (mainly) licensed under the GNU's Affero General Public License (AGPL). This license, provided by the Free Software Foundation, follows a principle called "copyleft". Copyleft says that code must be free software and works like this: "I make my code available for use in free software, and not for use in proprietary software, in order to encourage other people who write software to make it free as well. I figure that since proprietary software developers use copyright to stop us from sharing, we cooperators can use copyright to give other cooperators an advantage of their own: they can use our code" (Stallman 2010, 129). Copyleft uses existing property regimes to subvert them and uses the power of the right to property to avoid exclusive appropriation of software code (de Laat 2005; Wolf, Miller, and Grodzinsky 2009). It can be understood as a self-protecting measure for a specific mode of production and as an expression of the conflict that Marx has denoted. It is self-protecting for it requires any adaption of the free software code to be free software and licensed under the copyleft principle again. This clearly runs contrary to the capital strategy of excluding others in order to make profit. Copyleft suspends the capitalist logic within a limited realm because "the capital relation presupposes a complete separation between the workers and the ownership of the conditions for the realization of their labour" (Marx 1867/1976, 874).

In the case of Diaspora* and other free software, contributors really own the conditions for the realisation of their programming, thereby ensuring that work and the realisation of their work cannot be torn apart and alienated from each other. The distinction between being a consumer and producer is blurring within the realm of the Internet and SNS (Toffler 1980, Bruns 2008). So, users can become productive and contribute to the social network because they can, due to the freely available software, run their own pod or migrate from non-trustworthy pods to trustworthy ones. In the case of Diaspora*, we can see that the quality of the code level affects the user level and enables greater user control.

The previously quoted famous and controversial preface to $A$ Contribution to the Critique of Political Economy also claims that "the sum total of these relations of production constitutes the economic structure of society - the real foundation, on which rise legal and political superstructures and to which correspond definite forms of social consciousness [...]. With the change of the economic foundation, the entire immense superstructure is more or less rapidly transformed. In considering such transformations, the distinction should always be made between the material transformation of the economic condition of production [...] and the legal, political, religious, aesthetic or philosophic - in short ideological forms in which men become conscious of this conflict and fight it out" (Marx 1859/1909, 11f.). It is important to comment further on this quote. Marx says that the entire relations of production correspond with the social consciousness and ideas in different life spheres. He makes such claims from a very high level of abstraction; for him the passage is a guiding principle or a "leading threat" of investigation (Marx 1859/1909, 11). It is obvious that Diaspora*'s mode of production, apart from perhaps being a germ form of an alternative society (Fuchs 2009,77 ), does not represent contemporary society's entire relations of production. Furthermore, Marx points in this quote to a potential asynchrony between economic foundation and ideological superstructures. Both constraints denote the importance of analysing these very ideological structures.

Commercial SNSs consistently come into conflict with privacy and have evoked several public outcries. These include complaints against the leading SNS, Facebook, such as the complaints by the Electronic Privacy Information Center, the complaints by Austrian students addressed to the Irish Data Protection Commissioner (Europe versus Facebook 2011), or the investigation by the Nordic data inspection agencies (Datatilsynet 2011), which led to Diaspora*'s apparent quick success and distinctive self-understanding as a result of its focus on privacy. Diaspora* describes itself as "the privacy-aware, personally controlled, do-it-all open-source social network" (Diaspora* 2010). Its self-understanding distinguishes Diaspora* from the practices and the nature of dominant SNSs such as Facebook and Google+, and highlights how the site frames itself as an alternative SNS.

In order to be able to evaluate which role privacy can play in an alternative SNS project, I need to explain what privacy commonly entails (section 2) and how it fits into capitalist society (section $3)$. 


\section{Dominant Theories of Privacy: Individual Control, Exclusion, and Property}

The starting point of the modern privacy debate was an article by Samuel D. Warren and Louis D. Brandeis published in 1890. The motive for writing this article was an infringement during the wedding of Warren's daughter by the press. In this article, privacy is defined as the "right to be left alone" (Warren and Brandeis 1890/1984, 76). "The right to be left alone" is identical with the liberal core value of negative freedom (Rössler 2001, 20f.), and as such it determines most of the subsequent theoretical work on privacy and situates it within the liberal tradition. The plethora of values that are associated with privacy, such as the value of freedom, autonomy, personal well-being and so forth, mostly stem from this very kind of thinking. Serving these values, informational privacy is today most often defined either as control over the flow of information or over the access to information. For Alan F. Westin, "privacy is the claim of individuals, groups, or institutions to determine for themselves when, how, and to what extent information about them is communicated to others" (Westin 1967, 7). Westin focuses on the control of information, which makes him a prototypical proponent of "control-theories" of privacy (Tavani 2008, 142f.). On the other hand, there are "access-theories" of privacy (Tavani 2008, 141f.). Gavinson, for instance, relates privacy "to our concern over our accessibility to others: the extent to which we are known to others, the extent to which others have physical access to us, and the extent to which we are the subject of others' attention" (Gavinson 1980/1984, 347). If we combine these two major strands of privacy approaches, one can speak of privacy as individual control over access to personal information (Moor 1997; Tavani 2008). Some authors challenge the non-determination of "privacy as control" definitions (e.g., Wacks 2010, 40f.; Solove 2008, 25); they argue that these theories fail to define the content of privacy. In fact, control theories deal with the "freedom to choose privacy" (Wacks 2010, 41), rather than a determination of the content to be deemed private. Here, privacy is what is subjectively seen as private; such theories, therefore, foster individuals' exclusive control over their data, and do not want to and cannot lay claim to privacy within a good society and a happy fulfilled life (Jaggar 1983, 174). Access theories differ on this point; these theories can denote a realm of privacy that is not at the disposal of the individual's choice by any means (Fuchs 2011b, 223). For instance, such determinations of privacy could include the agreement that individuals' bodies, homes or financial issues such as bank secrecy, are inherently private. In access theories, privacy is what is objectively private and, therefore, theories as these can conjure up constraints to individuals' control over their data in terms of certain values. It is crucial to understand that access theories may allow thinking about what privacy should be in a good society, but not as a matter of necessity. In fact, access theories of privacy are also most often situated within the liberal tradition and have a limited notion of societal issues as the stress is on the individual control aspect.

A resemblance between privacy and property is often noted in the literature (Lyon 1994, 186; Laudon 1996, 93; Brenkert 1979, 126; Habermas 1991, 74; Goldring 1984, 308f.; Lessig 2002, 250; Hettinger 1989, 45; Geuss 2001, 103; Sofsky 2007, 95f.; Solove 2008, 26-28; Moore 2008, 420; Kang 1998; Litman 2000; Westin 1967, 324-325; Varian 1997; Samuelson 2000), but has rarely been analysed critically (exception: Fuchs 2011b).

A broad notion that expresses its fundamental character for human life and fits in with various kinds of property, understands property as a social relation with regard to (tangible and/or intangible) things (Pedersen 2010c). Macpherson speaks about three possible forms: private property, state property, and common property. He points out that private property and state property are of similar structure, since in both the social relation with regard to things is exclusionary (Macpherson 1978, 5). Macpherson further remarks upon three shifts in the property notion, which took place when capitalism and market society appeared (Macpherson 1978, 9f.). These shifts include relevant - and, as we shall see, ideological - identifications: private property, based on a relation of exclusion, is taken for property as such; property in the consumable means of life is identified with property in producing these means of life; and property in producing the means of life is identified with a specific property in producing the means of life, namely property of the labour force. These shifts are not arbitrary; rather, Macpherson argues that they are needed by market society and capitalism (Macpherson 1978, 9). Nowadays, private property is commonly associated with four aspects: the right to use, to abuse, to alienate or exchange something, as well as the right to receive the fruits that the usage of something generates (Munzer 2005, 858). Private property can be or probably has always been constrained by state or society (Christman 1996). However, "it may be called an absolute right in two senses: it is a right to dispose of, or alienate, as well as to use; and it is a right which is not conditional on the owner's performance of any social function" (Macpherson 1978, 10). 
A relation of exclusion lies behind privacy as well as in the case of private property. I will now point to some similarities between both concepts on a phenomenological level. In the next section, the resemblance is then explored more systematically using Marxian theory.

Most often, privacy is defined as an individual's right against others and society (ensuring negative freedom), so one may conclude that an opposition against 'the common' lies behind the privacy discourse. In the age of the Internet, "just as the individual concerned about privacy wants to control who gets access to what and when, the copyright holder wants to control who get access to what and when" (Lessig 2002, 250). Consequently, there is much discussion about how, on the one hand, to understand, justify, and criticize intangible private property, and on the other hand, to analyse, welcome, or mourn the blurring between the public and private realm online (with respect to SNS: boyd 2007). Further similarities between privacy and private property can be found in their dependence on people's class status (Goldring 1984, 313; Papacharissi 2010). It makes an important difference if one has private property only in things that one needs for life, or if one has much more private property than he or she needs for life. There are rich private property owners who possess far more housing space than they can ever use. On the other hand, there are poor private property owners, being on welfare, who only possess their labour power. In terms of privacy, there are, for instance, people who rely on sharing the flat with other people that brings along several constraints in temporarily withdrawing from other people, or they may be forced to report their whole private life to state authorities (Gilliom 2001). However, there are people who have far more privacy. For instance, people who live in castles are well protected from any unappreciated intrusions, be they from other people, noise, or anything else. These people may be able to circumvent reporting their financial status to state authorities, using the law effectively on their behalf by means of tax and investment consultants. As much as private property, privacy is also good for different things depending on one's class status. In capitalism, all people rely on having private property in order to satisfy their material and cultural needs. For the rich and powerful, private property ensures that they have the right to own the means of production and use them for their own purpose. For the poor, private property is essential because only via private property can they reproduce their labour power and ensure that they will make ends meet. In capitalism, all humans also rely on having privacy in order to be competitive within a society that forces them to compete, and at the same time to allow for spaces of escape from that competition (Geuss 2001, 88). Rich and powerful people's call for privacy is not only about individuation, but moreover about ensuring the sanctity of their wealth while hiding its origin (one thinks of bank secrecy, for instance). The poorer people also call for privacy in order to protect their lives against overexploitation and other forms of powerful abuse by the rich (Demirović 2004).

Not surprisingly, we know of theories that draw consequences from the outlined close connection between the individualistic control theory of privacy and private property by conceptualising the right to privacy as a right to property (Laudon 1996, 93; Lessig 2002; Kang 1998; Varian 1997). Property, according to the previously outlined identifying processes, is for these authors always to be understood as private property. Privacy as property would strengthen the individual control of personal data (Laudon 1996, 93; 97) and would prevent privacy invasions that occur when personal data is accessed non-consensually (Laudon 1996, 99). The "privacy as property"-approach demands that "everyone possesses information about themselves that would be valuable under some circumstances to others for commercial purposes. Everyone possesses his or her own reputation and data image. In this sense, basing privacy on the value of one's name is egalitarian. Even the poor possess their identity. In the current regime of privacy protection, not even the wealthy can protect their personal information" (Laudon 1996, 102). Admittedly, with other political implications in mind, Lessig says, in the context of privacy as property, that "property talk [...] would strengthen the rhetorical force behind privacy" (Lessig 2002, 247). If privacy is property, then it becomes possible to speak about theft regarding the non-consensual usage of personal data (Lessig 2002, 255).

\section{Privacy as Ideology and Privacy as Private Property: A Marxian Critique}

In this section, I will use Marxian theory to analyse dominant notions of privacy. Thereby I refer to Marx's concepts of ideology critique, commodity fetish, and his differentiation between a societal sphere of production and a societal sphere of circulation. Marx's concept of ideology critique is used as an umbrella theory that includes his analysis of fetishisms as well as the differentiation between a sphere of production and a sphere of circulation.

First, I must clarify what I mean by ideology. In general, ideology has different meanings. The term can be used neutrally to denote a worldview or a system of ideas. It can be used positively as a class struggle concept in order to mark positions within a struggle of beliefs. It can also be used 
denunciatively to dismiss ideas as negative or dogmatic, and the term can be used in the sense of the Enlightenment to point to an objectivity that is not yet present or known.

\subsection{Marx's Concept(s) of Ideology}

Marx has never outlined what he exactly understands by ideology; rather, there are different concepts of ideology notable in Marx's texts. Consequently, Marxist theory has developed different notions of ideology (Rehman 2007; Koivisto and Pietilä 1996; Žižek 1995; Eagleton 1991). I think that Marx's complete works show that he is committed to a concept of ideology that wants to enlighten through criticism (Rehmann 2007, 215), and I want to suggest a critical notion of ideology that includes three interacting aspects: a sociological, an epistemological, and a political dimension. All these aspects can be found in Marx. I propose that the problem of ideology consists of a specific form of human association that evokes a false consciousness as well as a structure of political domination.

Ideology as false consciousness is often associated with Marxist theory and its interest in enlightenment. Frederick Engels wrote in a letter to Franz Mehring that "ideology is a process accomplished by the so-called thinker consciously, indeed, but with a false consciousness" (Engels 1893). Obviously, ideology has to do with falseness and this is its epistemological aspect. However, it is often forgotten that Marx connects the question of truth strictly to human practice. Within the Theses on Feuerbach he expressed this very well: "The question whether objective truth can be attributed to human thinking is not a question of theory but is a practical question" (Marx 1845$46 / 1998,569)$. If the point is not only to interpret the world but to change it, as Marx suggested in the same manuscript (Marx 1845-46/1998, 571), then it becomes clear that ideology stops existing only if its societal preconditions cease to exist. For society, this demands changing practices and cannot be achieved solely through alternative "true" thinking. Marx interlinks epistemological questions of truth to sociological questions of human association and practice. In The German Ideology, Marx and Engels investigate forms of ideology along the modern division of labour between brain and hand. They introduce the societal role of the ideologist. Ideologists are removed from material production and can therefore imagine a "false" thinking which is detached from these processes (Marx and Engels 1845-46/1998, 67f.). Regarding The German Ideology, Terry Eagleton points towards a curious fusion of that epistemological aspect of ideology and a political definition (1991, 79f.), because Marx and Engels situate the labour division also in the context of class society and political domination. They argue that:

"The ideas of the ruling class are in every epoch the ruling ideas: i.e., the class which is the ruling material force of society is at the same time its ruling intellectual force. The class which has the means of material production at its disposal, consequently also controls the means of mental production, so that the ideas of those who lack the means of mental production are on the whole subject to it. The ruling ideas are nothing more than the ideal expression of the dominant material relations, the dominant material relations grasped as ideas; hence of the relations which make the one class the ruling one, therefore, the ideas of its dominance. The individuals composing the ruling class possess among other things consciousness, and therefore think. Insofar, therefore, as they rule as a class and determine the extent and compass of an historical epoch, it is self-evident that they do this in its whole range, hence among other things rule also as thinkers, as producers of ideas, and regulate the production and distribution of the ideas of their age: thus their ideas are the ruling ideas of the epoch" (Marx and Engels 1845-46/1998, 67).

Marx's talk of social relations here again points to the sociological aspect of ideology, and so we can reasonably claim that Marx's concept of ideology stems from a form of human association that evokes false consciousness and a structure of political domination.

\subsection{Objective Forms of Thought as Societal Impingement Structures of Privacy Ide- ologies}

If we do not assume a break in Marx's works but rather recognize a certain continuity, then we can understand his most important work, Capital, as a clarifying application of previously developed categories, such as ideology and others. At the same time, it might also be seen as a narrowing since it focuses on the field of economy. In terms of ideology, we can indeed find narrowing clarifications of that concept. Within Capital, as I shall outline and contextualise in terms of privacy, the specific form of sociological association is commodity exchange which gives rise to epistemological falseness and political domination. The epistemological falseness consists of naturalising humanmade relations, where political domination is maintained through the appropriation of societalproduced surplus by the capitalist. 
In Capital, Marx analyses "forms of thought which are socially valid, and therefore objective, for the relations of production belonging to this historically determined mode of social production, i.e. commodity production" (Marx 1867/1976, 169). These forms of thought tend to be dominant patterns of thinking, since commodity production and exchange are dominant in society. The process of commercialization of ever more spheres of life and human activities, such as education, media, ecology, human biology, and personality, is ongoing today and this means that ever more knowledge, content, natural resources, (genetic) codes, and personal data appear as exchangeable commodities. Critical philosopher Theodor W. Adorno argues that it is the principle of commodity exchange that determines the whole development of society (Adorno 2002, 31f.; 43; 112) or even human fatality (Adorno 1972, 209). Marx himself states that specific capitalist forms of thought influence "all the notions of justice held by both the worker and the capitalist, all the mystifications of the capitalist mode of production, all capitalism's illusions about freedom, all the apologetic tricks of vulgar economics" (Marx 1867/1976, 680). At the same time, one has to be careful not to universalise these forms of thought too much; it is important to stress that Marx highlights those forms of thought that have relevance for people in their role as marketers. While commodification plays a key role within ever more fields of activity, we are not only marketers. A second limitation of Marx's assertion is that we cannot expect to know everything about ideologies by only analysing forms of thought. Wolfgang Fritz Haug has suggested understanding Marx's investigations in Capital as societal impingement structures that are taken as a basis by and interact with the concrete work of ideologists (Haug 1987). I will try to mark points of intersection where objective forms of thought meet ideological privacy theories. Both privacy and property theories build on basal premises which are unquestioned because they originate from the marketer's common sense behaviour. Such forms of thought affect privacy and property theories, but the opposite is also true: privacy and property theories contribute to maintaining these forms of thought and the related forms of capitalist association. In the following, what objective forms of thought look like is explained and how they can be related to privacy and property.

\subsection{Marx's Fetish Argument: Deciphering Objective Forms of Thought}

Fetishism is used to denote inversions between subject and object, between humans and humanmade things or relations. According to Haug $(2005,161)$, investigating fetishisms means examining where man-made things exercise force over man. Marx addresses several fetishisms within Capital, starting with commodity fetishism. Marx observes that today, "the wealth of societies in which the capitalist mode of production prevails appears as an 'immense collection of commodities"' (Marx 1867/1976, 125), so that "only the products of mutually independent acts of labour, performed in isolation" are meaningful to be exchanged (Marx 1867/1976, 57). Commodity exchange presumes a certain historical development of the division of labour. Obviously, there are different companies producing essential things, to which I do not contribute. The way to get these things is to exchange them for money. In this sense, we are all marketers. Marx asks the question of why an exchange of so many different things, such as shoes, video games, personal data, etc. is possible at all: what makes them comparable and exchangeable? He finds an answer while analysing the specific sociality of private and isolated production that, however, appears as strictly non-social because there is no direct agreement or planning among producers over what and how much to produce.

Marx speaks of the differentiation between "abstract" and "concrete" labour as the crucial point for understanding the sociality of commodity production (Marx 1867/1976, 131-137). Any labour, however spent in isolation or in cooperation, produces use value that is valuable because it satisfies human needs. Such labour can be named "concrete" labour, as it contributes immediately to that end. However, when things are produced for exchange, then they have also an exchange value. Where does this exchange value come from? There must be a kind of labour, he named it "abstract" labour, that produces this value. As Marx's term suggests, abstract labour and the value that it produces are not tangible; rather, he argues that it originates from an abstraction: when two products are exchanged, a third moment, namely the exchange value that makes them comparable, arises. This happens just as one can speak of apples and strawberries as fruits, where the term "fruits" has the role of the mediating third that makes apples and strawberries comparable. The term "fruits" is an abstraction for apples and strawberries. In contrast to apples and strawberries, which are eatable and embody use value, the category "fruits" has no concrete use value. Marx says that exchange value originates within an abstraction; however, this abstraction is of an uncommon quality. It is not an abstraction in mind; rather it is an abstraction that evolves from the marketers' activities. The exchange process then can consequently be called "abstraction in reality", in contrast to common abstractions in mind. The "comparable becoming" of isolated and private 
workers within the exchange process, or in other words the value creation, is only possible because societal standards assert themselves within the exchange process. Otherwise, without comparison, no exchange would be possible at all. Such standards can be found in the amount of labour that is, on average, necessary to be spent to produce something (Marx 1867/1976, 129f.). The average necessary amount of labour, of course, clearly depends on the state of technology and the machines that are available for production. For instance, company $\mathrm{A}$ produces umbrellas and it takes 45 minutes to produce a piece, while company $B$ has introduced new machines and is able to produce the same piece in 15 minutes. If both companies would exchange their products then both of them would recognize that the value of umbrellas consists of 30 minutes labour time. But the companies do not know the value of their umbrellas before the exchange takes place, because they do not cooperate. Value does not appear before the exchange takes place; it can never be predicted beforehand (Marx 1867/1976, 166). The labour that is spent privately with a company has value only in relation to labour spent in the whole society (in all companies), and there is no institution that organizes the labour that is spent in the whole society. Companies A and B recognize the value of their products (30 minutes average necessary labour time) when they are exchanging their umbrellas. They receive the value in exchange for the umbrellas. For them, to be concerned with "how much of some other product they get for their own" (Marx 1867/1976, 167), it is obvious that their umbrella has this value as a property instead of it being built within a societal abstraction process (Marx 1867/1976, 187). The fact that labour creates value and that value is only recognisable in exchange and then determines further production is what Marx means when he speaks of the "phantom-like quality of value" (Marx 1867/1976, 128). He says:

"The mysterious character of the commodity-form consists therefore simply in the fact that the commodity reflects the societal characteristics of men's own labour as objective characteristics of the products of labour themselves, as the socio-natural properties of these things. Hence it also reflects the social relation of the producers to the sum total of labour as a social relation between objects, a relation which exists apart from and outside the producers" (Marx 1867/1976, 164f.).

The societal dimension of value creation is thus effectively "hidden" for marketers, but asserts itself behind people's backs (Marx 1867/1976, 135), because exchange value must be in the marketers' interest. They have exchange value and selling in mind when they start to produce and enter markets. Therefore, they adjust their activities according to the expected exchange value (Marx 1867/1976, 167).

The commodity fetish, which means that value is objectified in things, breaks the ground for a more highly developed fetishism, the money fetish. When value appears as a property of things, it is possible to imagine a specific commodity that objectifies value: money. Within money, exchange value and use value fall into each other; the use value of money is the exchange. The transition to independence of the law of value then becomes very concrete, and at the same time, the social quality of value becomes more "hidden". The fetish is thus perfected, and in fact, it is increasingly perfected in the further establishment of the capital relation. Ultimately, it appears that invested money itself begs money (capital fetish). I will come back to the capital relation in the following discussion.

\subsection{Privacy and the Mutual Recognition of Private Property Owners}

According to the premises of Marx's ideology theory, specific practices are related to specific forms of thought. In terms of the idea of a universal right to private property, Marx argues that marketers must "recognize each other as owners of private property. This juridical relation, whose form is the contract, whether as part of a developed legal system or not, is a relation between two wills which mirrors the economic relation" (Marx 1867/1976, 178). In the Grundrisse, Marx outlines this in detail. The mutual recognition of private property owners implies equality and freedom that are "not only respected in exchange based on exchange values but, also, the exchange of exchange values is the productive, real basis of all equality and freedom. As pure ideas they are merely the idealized expressions of this basis; as developed in juridical, political, social relations, they are merely this basis to a higher power" (Marx 1857-58/1983, 170).

Freedom is given within commodity exchange, as "individual A feels a need for the commodity of individual $B$, he does not appropriate it by force, nor vice versa, but rather they recognize one another reciprocally as proprietors, as persons whose will penetrates their commodities. Accordingly, the juridical moment of the Person enters here, as well as that of freedom, in so far as it is contained in the former. No one seizes hold of another's property by force. Each divests himself of his property voluntarily" (Marx 1857-58/1983, 169). Equality is given, since "only the differences between their needs and between their production give rise to exchange and to their social equation in exchange; these natural differences are therefore the precondition of their social equality in the 
act of exchange, and of this relation in general, in which they relate to one another as productive" (Marx 1857-58/1983, 168).

From the mutual recognition as private property owners, only formal equality between people can be deduced; the social status is not affected here. Also, freedom appears as very formal here. In Privacy: A Manifesto, Wolfgang Sofsky puts it this way:

"Exchange among private individuals is the basis for equality and freedom. Trading partners recognize each other as equals. Each accepts the other as a subject with his own will. The sales contract that they agree to does not establish equality of status or property but rather a voluntary relationship between peers. We should not expect more from a society that shields people from the pressure of the community and is supposed to put a protective distance between them" (Sofsky $2008,85 f$.).

In addition to freedom and equality, a third aspect is set within the commodity exchange, namely self-interest: "Individual A serves the need of individual B by means of the commodity a only in so far as and because individual $B$ serves the need of individual $A$ by means of the commodity $B$, and vice versa. Each serves the other in order to serve himself; each makes use of the other, reciprocally, as his means [...] That is, the common interest which appears as the motive of the act as a whole is recognized as a fact by both sides; but, as such, it is not the motive, but rather proceeds, as it were, behind the back of these self-reflected particular interests, behind the back of one individual's interest in opposition to that of the other" (Marx 1857-58/1983, 169f.).

In summary, Marx's differentiation between two societal spheres that are necessarily interwoven (Marx 1885/1992, 131f., 139, 190) may be helpful also for the theory of ideology. One sphere is about producing things and the labour that has to be spent on it. The other sphere is where the produced things circulate among people, i.e. the market. Equality, freedom, and self-interest appear in the latter.

"It is the exclusive realm of Freedom, Equality, Property and Bentham. Freedom, because both buyer and seller of a commodity, let us say of labour power, are determined only by their own free will. They contract as free persons, who are equal before the law. Their contract is the final result in which their joint will finds a common legal expression. Equality, because each enters into relation with the other, as with a simple Owner of commodities, and they exchange equivalent for equivalent. Property, because each disposes only of what is his own. And Bentham, because each looks only to his own advantage. The only force bringing them together, and putting them into relation with each other, is the selfishness, the gain and the private interest of each. Each pays heed to himself only, and no one worries about the others. And precisely for that reason, either in accordance with the pre-established harmony of things, or under the auspices of an omniscient providence, they all work together to their mutual advantage, for the common weal, and in the common interest" (Marx 1867/1976, 280).

By employing Marx's theory, I have thus far shown that the properties of the dominant privacy notion - competitive individualism, exclusive control, exchangeable private property - have their very origin in the commodity exchange. The commodity exchange hides human sociality. Value appears as property of things and not as a social relation. Hence, it is important to own things for realising their value. But sociality asserts itself behind people's back and establishes pressures to perform that are not controlled by the individuals. They perceive themselves as competitors.

C.B. Macpherson (1962) detected the great influence of the outlined objective forms of thought within the most influential philosophical and political thinking, from Hobbes to Locke, and labelled it "possessive individualism". Possessive individualism denotes a kind of thinking and a social practice. Within capitalism it is useful and necessary that the individual perceives herself or himself as essentially "the proprietor of his own person and capacities, for which he owes nothing to society" (Macpherson, 1962, 263) and enters "into self-interested relations with other individuals" (Macpherson 1962, 263). The value associated with privacy comes from these kinds of objective forms of thought. Admittedly, there has been much critique of this kind of privacy (Habermas 1991, 74; Lyon 1994, 186, 196; Etzioni 1999, 194), but for the evaluation of these critiques, it is important to keep in mind that privacy's origin in possessive individualism is not arbitrary; rather, this style of privacy originates from material, capitalist practices. There are also several newer privacy theories that do not proceed from the liberal individualistic point of view (for instance: Solove 2008, 91-98); however, the dominant mode of production in society remains bound to that point of view. We cannot simply define privacy differently without leaving social practices as they are.

\subsection{The Political Aspect: Privacy and Class Domination}

Ideology was defined as a specific form of human association that evokes a false consciousness and a structure of political domination. I have shown that it is in the associational form of commodi- 
ty exchange that ideology is falsified and thus makes privacy one-sided and individualistic. But what about the political dimension of ideology? I am stuck for an answer that addresses why ideology and therefore ideological notions of privacy are tied to implicit class domination and are therefore problematic. Marx gives an answer to this question within his capital theory. It is important to stress that there is a logical unity between the value theory and capital theory in Marx. The unity exists because commodity exchange and exploitation take place in capitalist reality at the same time. This means that commodity exchange and its objective forms of thought are necessarily interwoven with capitalism, i.e. we cannot separate them. And it also means that the dominant notion of privacy is related to the maintenance of political domination.

Marx describes capital as self-processing value (Marx 1867/1976, 257); in short, 'M-C-M': in the sphere of circulation, money (M) is invested for a specific commodity production (C) and results then, if the sale was successful, in more money (M'). Why are investments profitable? Marx gives the following answer. Self-processing value is possible due to the commodification of the workforce. The workforce is a certain commodity as it is able to produce more value than it costs to reproduce. For instance, food and opportunities for regeneration, such as free time, sleeping, etc. that have to be produced, are reproduction costs of the workforce. The difference between these costs and the surplus produced by workers is appropriated by the buyers of the workforce. In this manner, capitalists are steadily able to appropriate the societally-produced surplus by workers. They become therefore richer and more powerful than workers. Consequently, a structural class division in society becomes inevitable.

Why is such appropriation legitimate? It is legitimate because the principle of equivalence, "do ut des", "I give that you may give", no one cheats anyone, remains intact and therefore the mutual recognition as private property owners is not affected. On the contrary, fair commodity exchange and therefore the ideological notion of privacy - is presupposed for a capitalist class society. Not surprisingly, class society affects the privacy issue, as argued in section 2.

Marx argues that besides commodity exchange, i.e. labour performed privately and in isolation, capitalism needs to work out "a complete separation between the workers and the ownership of the conditions for the realization of their labour" (Marx 1867/1976, 874). In the prehistory of capitalism, this separation took place through a violent process of expropriation of great segments of the population, to which Marx refers as "primitive accumulation of capital" (Marx 1867/1976, part eight). Thereby, workers were set free, but this "liberation" was of ambiguous character. It resulted in a dual sense of freedom (Marx 1867/1976, 270-272), namely, workers are free of personal dependences, for instance, from their overlords in feudalism, but also free from the ownership of the condition for the realisation of their labour. Workers are on the one hand free to engage in contracts. This freedom is precisely the freedom of commodity exchange. On the other hand, workers are forced to engage in contracts and to sell their labour power on the markets to make ends meet. This freedom is also set in commodity exchange as it is a freedom to choose regardless of one's social status. Hence, workers are forced to maintain their status as a subaltern class because the capitalist can steadily appropriate the societal surplus that is produced by the workers (Marx $1867 / 1976,729 f$.). This fair exploitation process is, according to Marx, a structural reason for domination in society.

The capitalist quality of society as class society is expressed by the right to have others work for you and the right to private property in labour's terms of realisation. These rights are identified with the right to private property in general in an ideological manner (Macpherson 1978). Today's unitary legal frameworks for different sorts of private property are only possible because commodity exchange and appropriation of societally produced surplus are not divisible (Römer 1978, 140). The universal right to private property, to use, abuse, alienate or exchange something, and the right to receive the fruits that the usage of something generates, does not matter if only the things owned are needed for life, or the conditions within which labour can be realised (means of production) are private property, or if private property is extended to the labour force (Munzer 2005, 858).

In terms of privacy, Niels van Dijk $(2010,64)$ points to an interesting difference in legislation between Europe and the U.S. While in the U.S. tradition, personal data is predominantly seen as a commodity and therefore exchangeable (privacy as property), in Europe there is "little room for propertization of personal data" (van Dijk 2010, 64), because privacy is conceptualized as a persona right and important for the individual's dignity (McGeveran 2009; Shepherd 2012). But human dignity is generally seen as inalienable. In the discussion on the question whether privacy should or should not be alienable, exchangeable, and tradable on the markets, it is crucial to understand that in capitalism any commodification process presupposes rights that cannot be alienated or exchanged. The labourer must not become a slave, cannot alienate his or her whole person because this would reverse the double freedom of the labourer (Pateman 2002, 33). This is a feature of 
capitalist progress in comparison to previous forms of society. According to Marx, this means that domination, which still exists, is mediated through basic freedoms of the individual. Macpherson (1962, 264; see also Pateman 2002) argues that alienability of the labour force presupposes itself a universal, inalienable right of self-ownership that originates from the practice of commodity exchange and contains, as already outlined, the circulation sphere-based rights of freedom, equality, property, and self-interest (Marx 1867/1976, 280). In terms of privacy, I conclude that approaches to privacy as an inalienable right may be helpful but are ultimately not sufficient to be an alternative to capitalist class domination particularly if they operate with the notion of autonomy and privacy as self-possession.

Carole Pateman argues that the double freedom assigned to the worker in capitalism is a "political fiction" (Pateman and Mills 2007, 17f.) since the inalienable part of the individual that enters into employment contracts cannot be separated from the individual's alienable aspects. When employers buy work force, it is demanded that the worker brings in his or her knowledge, skills, etc., which in fact is his or her person. Labour cannot be separated from person-being and personbecoming (Marx 1976, 283). The same applies to privacy and personal data. It is a fiction to assume that users can exchange their personal data and that this exchange would not affect their person, which also has to be conceptualised as non-alienable in order to speak meaningfully of free and voluntary exchanges on privacy markets. Pateman argues that contracts, although entered voluntarily, enable superiority and subordination. Hence, there is also a subordination of the users at stake when they accept commercial SNSs' terms of use. Such subordination is a precondition for exploitation and class domination ultimately. Ellerman refers to this fiction as a "personthing mismatch" (Ellerman 2005, 463) as if aspects of personality could be alienated like things. The political fiction of severability of person and work force or person and personal data can easily be understood as ideology and fetishism in the sense that I have outlined it here.

Whereas privacy can, though ought not, be seen as an inalienable right, private property reasonably cannot (Andrew 1985, 529; Pateman 2002, 20-21; Litman 2000, 1295-1297). The closer privacy comes to private property, the more privacy is alienable or exchangeable, becoming itself a commodity. It does then not only contribute to the capitalist ideology, but also directly to exploitation. In Table 1, I summarise what we can learn from Marx in terms of understanding privacy in (informational) capitalism.

\begin{tabular}{|c|c|c|}
\hline \multirow{3}{*}{$\begin{array}{l}\text { ideology } \\
\text { societal sphere of } \\
\text { circulation }\end{array}$} & $\begin{array}{l}\text { privacy as aspect of self-ownership/ } \\
\text { privacy as inalienable right }\end{array}$ & \\
\hline & \multicolumn{2}{|c|}{ equal and free private property owners } \\
\hline & labour force commodity & $\begin{array}{l}\text { privacy as private property/ priva- } \\
\text { cy commodity }\end{array}$ \\
\hline \multirow[t]{2}{*}{$\begin{array}{l}\text { societal sphere of } \\
\text { production }\end{array}$} & classical exploitation & new forms of exploitation \\
\hline & \multicolumn{2}{|c|}{ appropriation of societally produced surplus and class domination } \\
\hline
\end{tabular}

Table 1: Ideological privacy and privacy as commodity in capitalism

Dominant theories of privacy, focussing on individual control and exclusion of others, are ideological as they originate from commodity exchange while hiding individuals' sociality. They are part of circulation sphere-based objective forms of thought that contain the mutual recognition of marketers as free and equal private property owners. Such freedom, equality, and lastly privacy, however, do not contradict exploitation and class division in society that take place in the sphere of production. In a circular movement, class status has then again a constraining effect on freedom, equality, and privacy. If privacy may be seen as exchangeable private property, privacy itself can in addition to labour force become a commodity and therefore part of the exploitation process. It contributes then directly to class divisions in society. Such newer forms of exploitation, based on economic 
surveillance, are described shortly in the next section, where Diaspora* is compared to profitoriented SNSs, such as Facebook and Google+.

\section{Evaluating Diaspora*'s Alternative Potential}

As the privacy issue is a core issue in Diaspora*'s self-image, evaluating Diaspora*'s alternative potential must include not only evaluating its mode of production, but also a critical evaluation of privacy as a whole. In the following, I will interlink both issues.

Christian Fuchs has outlined how we can analyse capital accumulation on SNSs in Marxian terms (Fuchs 2012, 143-146). Facebook's and others' capital accumulation strategy is mainly based on the targeted advertising business model, which means that they engage in exchange contracts with the advertising industry. The owner buys technical infrastructure, such as server parks and software components, as well as labour force, such as accountants, software developer, etc, and produces the SNS on which users can interact. While people use the site for different reasons, such as getting news, providing information, staying in touch with friends, making new relations, or organising events, they produce a wide range of data. These data, which include for instance socio-demographic information and consumer preferences deduced from users' browsing behaviour, are then sold to advertisers. Whereas traditional forms of advertising are directed to broad groups of potential buyers, targeted advertising is tailored for exactly defined and differentiated groups, or even single consumers. This demands more detailed, exact, and differentiated knowledge of the users' needs and (buying) behaviour, which can be provided by the owner of SNSs. The SNSs' business model is based on the secondary use of user interaction for commodification and valorisation purposes (Smythe 1989; Fuchs 2011a). The economic reason why profitoriented SNSs develop massive systems of user surveillance and store "literally everything", as a Facebook employee has admitted (Wong 2010), lies therein. Users' interests in privacy can only be considered where the need for privacy does not inhibit SNSs' profit interests. In fact, commercial SNSs commodify users' privacy. They often do it without users' explicit consent, when they hide their profit-orientation behind the social value of networking. Today, SNSs are increasingly compelled to respect users' privacy through legal investigations, public pressure initiated by privacy movements, and alternative SNSs such as Diaspora*, but this does not mean that commercial SNSs have to abjure the targeted advertising model. Commercial and advertising funded SNSs need users who have control over their data and are able to exchange their privacy for the usage of the platform voluntarily by agreeing to the terms of use. For them, in order to maintain newer forms of exploitation, the challenge is not to fight against privacy at all; rather, they can support privacy if it is - as an analogy to labour force - related to private property, and hence alienable or exchangeable. It seems that simply upholding privacy is not the right move in order to challenge surveillance (Nock 1993, 1; Lyon 2005, 27; Stalder 2002).

Diaspora* breaks with this advertising model based on privacy as commodity; hence, it protects its users and their personal data from exploitation: "Yet our distributed design means no big corporation will ever control Diaspora. Diaspora* will never sell your social life to advertisers, and you won't have to conform to someone's arbitrary rules or look over your shoulder before you speak" (Diaspora 2011c; emphasis in original). Gary T. Marx reminds us that "privacy for whom and surveillance of whom and by whom and for what reasons need to be specified in any assessment" (Marx 2012, vii). Due to its distributed infrastructure and its funding model that is not based on advertising, one can argue that Diaspora* practically provides an alternative concept of privacy (Fuchs 2012, 153f.). Diaspora* sees "privacy as collective right of dominated and exploited groups that need to be protected from corporate domination that aims at gathering information about workers and consumers for accumulating capital, disciplining workers and consumers, and for increasing the productivity of capitalist production and advertising" (Fuchs 2011b, 232).

While I agree that Diaspora* practically avoids commodification of privacy and the exploitation of users, I nevertheless see some constraints for an alternative non-ideological notion of privacy that follows from my preceding analysis. Not only is treating privacy as commodity a problem but it should also be taken into account that conceptualising privacy as an aspect of self-ownership is ideological and cannot be separated from exploitation in capitalism. In fact, although Diaspora* is directed against newer forms of exploitation of users' privacy, its recourse to privacy remains bound to exploitation in general as it confirms exploitation's ideological premises - the possessive individualistic ideology. I shall provide evidence for such a claim.

In its various self-descriptions Diaspora* prominently states: It "is the social network that puts you in control of your information. You decide what you'd like to share, and with whom. You retain full ownership of all your information, including friend lists, messages, photos, and profile details" (Diaspora* n.d.b; my emphasis). Here, two aspects are intertwined: Diaspora* refers to a specific 
notion of privacy ("puts you in control of your information") and relates the promise of user control to property ("You retain full ownership of all your information").

Dominant privacy theories stress the individual's control over access to personal information and are deeply rooted in people's minds and their practical role as marketers. Privacy-aware users, who see commercial SNSs as associated with privacy invasive behaviour, are surely attracted by Diaspora*'s privacy statement. One consequence of privacy theories stressing the individual control aspect is that they avoid objective constraints of the individual's power to control and decide. The public good finds no consideration here. Another alternative SNS in the making, TheGlobalSquare, which is associated with the "occupy" movement (Roos 2011), also relates to the privacy discourse. It makes more substantial claims about what privacy is and what it is not: "Individuals have a right to privacy as part of the rights they brought from a state of nature [...]. Organizations and actions which affect the public are not protected by any such rights" (Marsh 2012). Here, individual control is not seen exclusively and this example proves that Diaspora* could also behave differently in its recourse to the value of privacy. As far as I can see, in its various self-descriptions, Diaspora* does not propose any qualification of privacy that can constrain exclusive individual control and is therefore likely to fit into the dominant theories of privacy. Diaspora* mobilises the power of the individuals and their privacy - for which they think that they owe nothing to society - against economic surveillance. So, it challenges successfully the economic foundations underlying privacy threats, but does not challenge privacy as a possessive individualistic concept.

On the contrary, Diaspora*'s focus on privacy is accompanied by stressing the relevance of ownership. Concepts of ownership or private property support the exclusive and individualistic notion of privacy. Here again, Diaspora* reacts to commercial SNSs. Facebook, for example, states in its terms of use that users grant Facebook "a non-exclusive, transferable, sub-licensable, royaltyfree, worldwide license to use any IP [intellectual property] content that you post on or in connection with Facebook" (Facebook 2011). In the case of Diaspora*, such a license is not possible. However, in the same passage, Facebook also states that "you own all of the content and information you post on Facebook, and you can control how it is shared through your privacy and application settings" (Facebook 2011). Is the notion of ownership then so appropriate for an alternative to capitalist SNSs? I think it is not and the relationship between privacy as commodity (the Facebook license for instance) and privacy as an aspect of self-possession (Diaspora*'s notion), which has been outlined above, gives grounds for holding a sceptical view. Diaspora*'s vision of privacy protection is, as outlined in the first section, essentially based on the individual opportunity to change pods/SNS-provider. Users need ownership of their data in order to migrate them from pod to pod: "And because your information is yours, not ours, you'll have the ultimate power - the ability to move your profile and all your social data from one pod to another, without sacrificing your connection to the social web" (Diaspora 2011c; emphasis in original). Assuming that Diaspora* will never be able to outdo Facebook in terms of provided features and network effects in the view of the majority of SNSs users, users may then voluntarily decide to sell their privacy on Facebook or Google+ and they are indeed able to do this as they have exclusive control and ownership of their privacy. Exactly, these premises of the privacy commodity exchange are also propagated by Diaspora*. The dominant theoretical privacy concept cannot provide reasons why users should not behave like this.

At this point of Diaspora*'s evaluation, it may be useful to remember Marx's "leading threat" of investigation expressed in the previously quoted passage from the preface to $A$ Contribution to the Critique of Political Economy, where he refers to the relation between the entire economic foundation of society and the more or less rapidly transforming superstructures within which humans become conscious of conflicts and fight them out. The focus on privacy, as it is dominant in capitalism, may result from Diaspora*'s multi-faceted embeddedness in capitalist structures.

There is capital accumulation related to copyleft. On the one hand, copyleft products can be used for free in order to produce non copyleft products. For instance, machines that produce umbrellas can be operated on behalf of free and copyleft software. The producer of umbrellas does not have to pay for that kind of software although it contributes as means of production to his or her capital accumulation. In this case, an intensive exploitation of the labour that was once spent on the copyleft product takes place. The producer of umbrellas saves the money that he or she would otherwise have to pay for the machine's operating software. On the other hand, copyleft products are attractive for users as they cheap, widely cheaply accessible and have a high quality since a huge pool of co-operative labour builds them. Copyleft products are also often more flexibly adaptable to specific purposes. This appeal can be used for capital accumulation indirectly. Commercial firms may offer services that are related to copyleft products. For instance, a producer of umbrellas pays another firm that collects and aggregates suitable copyleft components for running umbrella- 
producing machines. In this case, it is not the labour spent on producing the copyleft product that contributes directly to capital accumulation, but rather the labour spent on collection and service. I argue that copyleft production is indeed opposed to capital accumulation. However, at the same time, it allows for newer forms of exploitation that can be much more intensive - the producer of umbrellas pays nothing for the use of copyleft products, but these products enable him to realise surplus through selling the umbrellas.

A major problem in this context is that copyleft is not the dominant principle of production; rather, it can be understood as an expression of a transforming economic foundation in a partial realm and therefore capital accumulation can behave parasitical to copyleft production. Diaspora*'s mode of production is bound to the immaterial or informational realm. In terms of political economic theories of this realm, it can be differentiated in terms of three approaches, as Fuchs $(2009,79)$ argues. A neoliberal position wants to take back peer-production by enforcing intellectual private property rights and the principle of exclusion. A social democratic position sees advantages in initiatives such as Free Software and Diaspora*, but seeks to establish a kind of dual economy. Pedersen calls this position "information exceptionalism". Informational exceptionalists reject property rights in the intangible realm, but do not challenge them in the tangible realm: "The market is good for humanity, as long as it behaves nicely in cyberspace" (Pedersen 2010b, 105). A way to explain the difference between the two positions is to understand informational exceptionalists as representing a distinct group of capital interests. While there are corporations making profit by enforcing intellectual private property rights, there are other corporations, such as Google, which gain profits without enforcing intellectual property rights but are ultimately dependent of private property rights in the tangible realm (Söderberg 2002).

A third position mentioned by Fuchs $(2009,79)$ aims to transcend capitalism and sees the intangible realm as a germ form of a new mode of production for the whole society - also within the tangible realm. At the same time, this position always stresses the fragility of peer-productions by pointing to their dependence on dominant capitalist social relations (Barbrook 1998/2005). In terms of Diaspora*'s mode of production, the following argument made by Söderberg can be applied. It is "a prerequisite of free programming [...] that those involved are sustained outside of market relations. Hackers are generally supported financially in diverse ways - by their parents, as students living on grants, as dropouts getting by on social benefits, or even employees within computer companies - and their existence is linked to the burgeoning material surplus of informational capitalism" (Söderberg 2002). Also, the donation funding system applied by Diaspora* remains embedded in capitalist structures. The value objectified in money donations has to be produced in capitalist structures. Capitalists themselves may donate out of idealistic reasons, but probably most of the donations stem from wage labourers. One can glean from an interview with the Diaspora* founders that there are different meanings among the project team on whether Diaspora* will and should make money in the future (Nussbaum 2010). Software contributors to Diaspora* cannot live without an income and the project's fund of donations is finite (Diaspora* 2011a), which is a general problem that all alternative media are facing. Hence, "the team has spoken to venture capitalists and others who want in on the project, although so far, they have remained independent", as reported in a New York Magazine article on Diaspora* (Nussbaum 2010).

Interestingly, in this context of capitalist embeddedness, Diaspora*'s mode of production itself offers at least a gateway to suspend the copyleft principle and allows capital accumulation more directly. Besides using a copyleft license (GNU Affero General Public License), which makes it and all adoptions of it free software and ensures or even extends the alternative mode of production, Diaspora* also uses a compatible but different kind of license (MIT/X11 license). The difference between both licenses is that the latter is not "viral" or self-protecting. That means Diaspora is allowed "to license general-use components of the Diaspora ${ }^{\mathrm{TM}}$ Software (e.g., parsers for standard formats, libraries implementing standard protocols, etc.)" not protected by copyleft (Diaspora* 2011b). Indeed, the software code cannot be used directly for proprietary and profit-generating reasons, although indirectly it can (Fitzgerald 2006, de Laat 2005).

The preceding evaluation of Diaspora* has shown that the project and its alternative mode of production are open to be exploited by capitalist modes of production and capital strategies in the informational age (Chopra and Dexter 2006).

Diaspora* performs practically an alternative concept of privacy that protects users from commodification, but at the same time does not aim at an alternative to a possessive-individualistic privacy notion. As such, this is not contradictory and may rest with Diaspora*'s multi-faceted - wilfully or not - embeddedness within capitalist structures that are dominant in society and remain dominant in people's minds. However, in order to strengthen the alternative quality of Diaspora* and other non-commercial SNSs, the privacy issue and its possessive individualistic capitalist coin- 
age should be rethought and not simply be permitted to enter the discourse about alternative SNSs.

\section{Conclusion}

Diaspora* challenges commodity production; hence, it challenges capital accumulation in the realm of SNSs. Its alternative and cooperative mode of production provides, according to ideology theory, a base for thinking about an alternative notion of privacy. I have argued that an alternative notion of privacy demands grounding in alternative material practices since the dominant notion of privacy is associated with commodity exchange. Thinking about an alternative notion of privacy instead of abandoning it is relevant and worthy as privacy, although predominantly occupied by possessive individualistic concepts such as exclusion and private property, also represents the basal human need of individuality that cannot be meaningfully denied by any alternative form of society. As far as I can see, there is no positive Marxist theory of privacy and I cannot provide one here. Marx's focus on a negative critique of capitalism first and foremost aims to abolish social structures that inhibit human potentials and creativity. Following this tradition, Fuchs (2011b) and Allmer (2011) provide some critical remarks for a socialist notion of privacy. I tried to apply myself Marx's negative critique on capitalist ideology and private property to privacy, following the often mentioned connection between both of the latter terms.

However, an alternative vision of privacy must contain more than an opposition to societal relations of inequality; rather it should constructively theorise the value of privacy alternatively and based on a "social conception of individuality" (Pateman 1989, 136). It is an important theoretical task to reflect on an alternative relation between the individual and society and various approaches that take seriously the critique of individualistic privacy notions are taking this path (for instance: Solove 2008, 91-98; Cohen 2012). Unfortunately, these approaches do not engage with Marx's profound analysis of capitalist domination structures. In his fetish analysis, Marx has shown that the individual, following the commodity exchange induced assumption that he or she owes nothing to society, cannot get rid of society. Society asserts itself behind individuals' backs and predetermines their behaviour. Accepting and consciously shaping sociality would be the better option. Taking privacy as an individual claim that excludes others and is raised against society from the outset thus makes no sense at all. Privacy can only be a "societal license" (Etzioni 1999, 196). It is a collective task on how best to satisfy individual privacy needs, such as a home, being alone, silence, reflection, recreation, freedom of expression and decision-making, personal and intimate relations, trust and respect, secrecy, and protection from harm. Pure subjective control theories of privacy should be rejected. Instead, comprehensive democratic structures are required to enable individuals to effectively shape their privacy license in association with others. However, privacy is then not my property and I cannot exchange it and contract it out; it is then a collectively achieved individual value that I can only claim as a member of society. Understanding privacy as an aspect of selfpossession then makes no sense. It should be conceptualised as an inalienable collective right.

Objective notions of privacy as an outcome of conscious association are needed, and Diaspora* has practically developed one: it is based on the idea of privacy for SNS users that challenges economic surveillance. As a consequence, the idea of the exploitation of users and the commodification of data, as done by Facebook and Google+, is rejected. Contributors to Diaspora* are associating themselves consciously, not mediated by commodity exchange, but on behalf of copyleft. They have created an objective notion of privacy in and through their practices. This is vital since a basal assumption of Marx was that there would be no individuality, freedom, autonomy, and privacy as long as there is systematic exploitation and class domination in society. It turns out that what is easier to accept as a starting point for theory, i.e. a societal concept of privacy, is much harder to achieve for Diaspora*, although some consequences of this concept are already realised in Diaspora*'s opposition to exploitation. Diaspora* provides an alternative to privacy commodification and user exploitation, but its struggle is fought out on the ideological battlefield of privacy which is not a neutral one, and is rather predetermined by possessive individualistic thinking that objectively contradicts Diaspora*'s alternative goals. Diaspora* refers to ownership and individual control exactly because these are the most powerful means of action in capitalism. I have introduced views, such as informational exceptionalism, that welcome changes in the intangible mode of production, but do not challenge capital accumulation in general. Sticking to possessive individualistic premises, albeit in terms of privacy, may ultimately refer to an immanent transformation of capitalism that reproduces the overall system rather than to a real alternative to it.

The challenge for a Marxist theory of privacy and for alternative SNSs, such as Diaspora*, is to thoroughly disentangle privacy from private property (Goldring 1984, 321f.) in such a way that privacy neither appears as a commodity itself nor contributes to the ideological premises of commodi- 
ty production and capital accumulation. A material base for such thinking can already be found in Diaspora*, copyleft, and projects of a similar nature.

\section{References}

Adorno, Theodor W. 1972. Society. In The Legacy of the German Refugee Intellectuals, edited by Robert Boyers. New York: Schocken.

Adorno, Theodor W. 1976. On the Logic of the Social Sciences. In The Positivist Dispute in German Sociology, edited by Theodor W. Adorno, Hans Albert, Ralf Dahrendorf, Jürgen Habermas, Harald Pilot, and Karl R. Popper, 105-122. London: Heinemann.

Adorno, Theodor W. 2002. Introduction to Sociology. Stanford, CA: Stanford University Press.

Allmer, Thomas. 2011. A Critical Contribution to Theoretical Foundations of Privacy Studies. Journal of Information, Communication and Ethics in Society 9 (2): 83-101.

Andrew, Edward. 1985. Inalienable Right, Alienable Property and Freedom of Choice: Locke, Nozick and Marx on the Alienability of Labour. Canadian Journal of Political Science 18 (3): 529-550.

Barbrook, Richard. 1998. The Hi-Tech Gift Economy. First Monday Special Issue 3. http://www.firstmonday.org/htbin/cgiwrap/bin/ojs/index.php/fm/article/view/1517/1432

Bauwens, Michel. 2006. The Political Economy of Peer Production. Post-autistic Economics Review 37: 33-44.

Benkler, Yochai. 2006. The Wealth of Networks: How Social Production Transforms Markets and Freedom. New Haven: Yale University Press.

boyd, danah. 2007. Social Network Sites: Public, Private, or What? Knowledge Tree 13. http://www.danah.org/papers/KnowledgeTree.pdf

Brenkert, George G. 1979. Freedom and Private Property in Marx. Philosophy and Public Affairs 8 (2): 122-147.

Bruns, Axel. 2008. Blogs, Wikipedia, Second Life, and Beyond: From Production to Produsage. New York: Peter Lang.

Chopra, Samir and Scott Dexter. 2006. The Political Economy of Open Source Software. Accessed February 25, 2012. http://www.sci.brooklyn.cuny.edu/ sdexter/Pubs/chopra-dexter-TC05-paper.doc

Christman, John. 1994. The Myth of Property: Toward an Egalitarian Theory of Ownership. Oxford: Oxford University Press.

Cohen, Julie E. 2012. Configuring the Networked Self: Law, Code, and the Play of Everyday Practice. New Haven: Yale University Press.

Datasilnet. 2011. Questions to Facebook from the Nordic DPA's. Accessed February 25, 2012. http://www.datatilsynet.no/upload/Dokumenter/utredninger\%20av\%20Datatilsynet/Letter\%20with\%20questions $\% 20$ to\% 20Facebook\%20from\%20nordic\%20countries\%20endellig.pdf

Demirović, Alex. 2004. Hegemony and the Paradox of Public and Private. Accessed February 25, 2012. http://www.republicart.net/disc/publicum/demirovic01_en.htm

Diaspora*. n.d.a. The Diaspora* Project. Accessed February 25, 2012. http://diasporaproject.org/

Diaspora*. n.d.b. JoinDiaspora* blog entry "What is Diaspora*”. Accessed October 23, 2011. http://blog.joindiaspora.com/what-is-diaspora.html

Diaspora*. 2010. Flyer about Diaspora*. Accessed February 25, 2012. http://blog.joindiaspora.com/2010/04/24/awesomeflyers-are-here.html

Diaspora*. 2011a. Diaspora* blog entry "Diaspora* is Back in Action". Accessed February 25, 2012. http://blog.diasporafoundation.org/page/2

Diaspora*. 2011b. Diaspora* Contributor Agreement. Accessed February 25, 2012. https://github.com/Diaspora/Diaspora/wiki/New-CLA--12-13-10

Diaspora*. 2011c. Diaspora* blog entry "Diaspora* Means a Brighter Future for All of Us". Accessed March 6, 2012.

http://blog.diasporafoundation.org/page/5

Diaspora*. 2012. The Official Diaspora* Wiki entry "Why Client Side Encryption is a Bad Idea“. Accessed February 25, 2012. https://github.com/Diaspora/Diaspora/wiki/Why-client-side-encryption-is-a-bad-idea

van Dijk, Niels. 2010. Property, Privacy and Personhood in a World of Ambient Intelligence. Ethics and Information Technology 12 (1): 57-69.

Eagleton, Terry. 1991. Ideology: An Introduction. London: Verso.

Ellerman, David. 2005. Translatio Versus Concessio: Retrieving the Debate About Contracts of Alienation with an Application to Today's Employment Contract. Politics \& Society 33 (3): 449-480.

Engels, Frederick. 1893. Letter to Franz Mehring from July 14, 1893. Accessed February 25, 2012. http://www.marxists.org/archive/marx/works/1893/letters/93_07_14.htm

Etzioni, Amitai. 1999. The Limits of Privacy. New York: Basic Books.

Europe versus Facebook. 2011. Complaints against 'Facebook Ireland Limited'. Accessed February 25, 2012. http://www.europe-v-facebook.org/EN/Complaints/complaints.html

Facebook. 2011. Statement of Rights and Responsibilities. Accessed March 6, 2012. https://www.facebook.com/legal/terms

Fitzgerald, Brian. 2006. The Transformation of Open Source Software. Management Information Systems Quarterly 30 (3): 587-598.

Fredom Box Foundation. n. d. Flyer about the FreedomBox. Accessed February 25, 2012. http://freedomboxfoundation.org/doc/flyer.pdf

Fuchs, Christian. 2009. Information and Communication Technologies and Society: A Contribution to the Critique of the Political Economy of the Internet. European Journal of Communication 24 (1): 69-87.

Fuchs, Christian. 2011a. Web 2.0, Prosumption, and Surveillance. Surveillance \& Society 8 (3): 288-309.

Fuchs, Christian. 2011b. Towards an Alternative Concept of Privacy. Journal of Information, Communication and Ethics in Society 9 (4): 220-237.

Fuchs, Christian. 2012. The Political Economy of Privacy on Facebook. Television \& New Media 13 (2): 139-159.

Gavinson, Ruth. 1980. Privacy and the Limits of Law. In Philosophical Dimensions of Privacy: An Anthology, edited by Ferdinand Schoeman, 346-402. Cambridge: Cambridge University Press.

Geuss, Raymond. 2001. Public Goods, Private Goods. Princeton: Princeton University Press. 
Gilliom, John. 2001. Overseers of the Poor: Surveillance, Resistance, and the Limits of Privacy. Chicago: University of Chicago Press.

Goldring, John. 1984. Privacy and Property. The Australien Quarterly 56 (4): 308-324.

Habermas, Jürgen. 1991. The Structural Transformation of the Public Sphere: An Inquiry into a Category of Bourgeois Society. Cambridge: MIT Press.

Haug, Wolfgang Fritz. 1987. Outlines for a Theory of the Ideological. In Commodity Aesthetics, Ideology and Culture, edited by Wolfgang Fritz Haug, 59-99. New York: International General.

Haug. 2005. Vorlesungen zur Einführung ins "Kapital". Berlin: Argument.

Hettinger, Edwin C. 1989. Justifiying Intellectual Property. Philosophy and Public Affairs 18 (1): $31-52$.

Jaggar, Alison. 1983. Feminist Politics and Human Nature. Totowa: Rowman \& Allanheld.

Kang, Jerry. 1998. Information Privacy in Cyberspace Transactions. Stanford Law Review 50 (4): 1193-1294.

Koivisto, Juha and Veikko Pietilä. 1996. Ideological Powers and Resistance: The Contribution of W. F. Haug and Projekt Ideologie-Theorie. Rethinking Marxism 9 (4): 40-59.

de Laat, Paul B. 2005. Copyright or Copyleft?: An Analysis of Property Regimes for Software Development. Research Policy 34 (10): 1511-1532.

Laudon, Kenneth C. 1996. Markets and Privacy. Communications of the ACM 39 (9): 92-104.

Lessig, Lawrence. 2002. Privacy as Property. Social Research 69 (1): 247-269.

Litman, Jessica. 2000. Information Privacy/Information Property. Stanford Law Review 52 (5): $1283-1313$.

Lyon, David. 1994. The Electronic Eye: The Rise of Surveillance Society. Minneapolis: University of Minnesota Press.

Lyon, David. 2005. Surveillance Society: Monitoring Everyday Life. Buckingham: Open University Press.

Macpherson, Crawford B. 1962. The Political Theory of Possessive Individualism: Hobbes to Locke. Oxford: Clarendon Press.

Macpherson, Crawford B. 1978. The Meaning of Property. In Property: Mainstream and Critical Positions, edited by Crawford B. Macpherson, 1-13. Toronto: University of Toronto Press.

Marsch, Heather. 2012. A Proposal for Governance: Privacy and Transparency. Accessed February 25, 2012. http://wlcentral.org/node/2445

Marx, Gary T. 2012. Foreword: Privacy Is Not Quite Like the Weather. In Privacy Impact Assessment, edited by David Wright and Paul de Hert, v-xiv. Dordrecht: Springer.

Marx, Karl. 1849/2006. Wage-labour and Capital. In Wage-labour and Capital \& Value, Price, Profit. New York: International Publishers.

Marx, Karl. 1857-58/1983. Grundrisse der Kritik der Politischen Ökonomie. In Marx Engels Werke (MEW), Band 43. Berlin: Dietz. English translation accessed February 25, 2012. http://www.marxists.org/archive/marx/works/download/Marx Grundrisse.pdf

Marx, Karl. 1859/1909. A Contribution to the Critique of Political Economy. Chicago: Charles H. Kerr \& Company.

Marx, Karl. 1867/1976. Capital: A Critique of Political Economy: Volume One. Middlesex: Penguin.

Marx, Karl. 1885/1992. Capital: A Critique of Political Economy: Volume Two. Middlesex: Penguin.

Marx, Karl. 1845/1998. Theses on Feuerbach. In The German Ideology Including Theses on Feuerbach and Introduction to the Critique of the Political Economy, 569-571. Amherst: Prometheus.

Marx, Karl and Frederick Engels. 1845-46/1998. The German Ideology. In The German Ideology Including Theses on Feuerbach and Introduction to the Critique of the Political Economy, 27-658. Amherst: Prometheus.

McGeveran, William. 2009. Disclosure, Endorsement, and Identity in Social Marketing. University of Illinois Law Review 2009 (4): 1105-1166.

Moglen, Eben. The dotCommunist Manifesto. Accessed March 20, 2012 http://emoglen.law.columbia.edu/my pubs/dcm.html

Moglen, Eben. 2010. Freedom in the Cloud: Software Freedom, Privacy, and Security for Web 2.0 and Cloud Computing. Accessed February 25, 2012. http://www.softwarefreedom.org/events/2010/isoc-ny/FreedomlnTheCloud-transcript.html

Moor, James H. 1997. Towards a Theory of Privacy in the Information Age. Computers and Society 27 (3): $27-32$.

Moore, Adam D. 2008. Defining Privacy. Journal of Social Philosophy 39 (3): 411-428.

Munzer, Stephen R. 2005. Property. In The Shorter Routledge Encyclopedia of Philosophy, edited by Edward Craig, 858861. London: Routledge.

Nock, Steven. 1993. The Costs of Privacy: Surveillance and Reputation in America. New York: de Gruyter.

Nussbaum, Emily. 2010. Defacebook: Four Young Friends Who Are Out to Create a Very Different Sort of Social Network. New York Magazine, September 26, 2010. Accessed February 25, 2012. http://nymag.com/news/features/establishments/68512/

Papacharisi, Zizi. 2010. Privacy as a Luxury Commodity. First Monday 15 (8). Accessed February $25,2012$. http://firstmonday.org/htbin/cgiwrap/bin/ojs/index.php/fm/article/viewArticle/3075/2581

Pateman, Carole. 1989. The Disorder of Women: Democracy, Feminism, and Political Theory. Stanford: Stanford University Press.

Pateman, Carole. 2002. Self-ownership and Property in the Person: Democratization and a Tale of Two Concepts. Journal of Political Philosophy 10 (1): 20-53.

Pateman, Carole and Charles W. Mills. 2007. Contract and Domination. Cambridge: Polity.

Pedersen, J. Martin. 2010a. Free Culture in Context: Property and the Politics of Free Software. The Commoner 14: 49136.

Pedersen, J. Martin. 2010b. Properties of Property: A Jurisprudential Analysis. The Commoner 14: 137-210.

Pedersen, J. Martin. 2010c. Free Software as Property. The Commoner 14: 211-286.

Raynes-Goldie, Kate. 2010. Aliases, Creeping, and Wall Cleaning: Understanding Privacy in the Age of Facebook. First Monday 15 (1). Accessed February 25, 2012.

http://firstmonday.org/htbin/cgiwrap/bin/ojs/index.php/fm/article/view/2775/2432

Rehmann, Jan. 2007. Ideology Theory. Historical Materialism 15 (4): 211-239.

Römer, Peter. 1978. Entstehung, Rechtsform und Funktion des kapitalistischen Privateigentums. Köln: Pahl-Rugenstein. 
Roos, Jerome. 2011. The Global Square: An Online Platform for Our Movement. Accessed February 25, 2012. http://roarmag.org/2011/11/the-global-square-an-online-platform-for-our-movement/

Rössler, Beate. 2001. Der Wert des Privaten. Frankfurt am Main: Suhrkamp.

Samuelson, Pamela. 2000. Privacy as Intellectual Property? Stanford Law Review 52 (5): 1125-1173.

Shepherd, Tamara. 2012. Persona Rights for User-generated Content: A Normative Framework for Privacy and Intellectual Property Regulation. tripleC 10 (1): 100-113.

Smythe, Dallas W. 2006. On the Audience Commodity and Its Work. In Media and Cultural Studies: Keyworks, edited by Durham G. Meenakshi and Douglas Kellner, 230-256. Malden: Blackwell.

Söderberg, Johan. 2002. Copyleft Vs. Copyright: A Marxist Critique. First Monday 7 (3-4). Accessed February 25, 2012. http://www.firstmonday.org/htbin/cgiwrap/bin/ojs/index.php/fm/article/viewArticle/938/860

Sofsky, Wolfgang. 2008. Privacy: A Manifesto. Princeton: Princeton University Press.

Solove, Daniel J. 2009. Understanding Privacy. Cambridge: Harvard University Press.

Stalder, Felix. 2002. Opinion: Privacy Is Not the Antidote to Surveillance. Surveillance \& Society 1 (1): 120-124.

Stallman, Richard M. 2010. Copyleft: Pragmatic Idealism. In Free Software, Free Society: Selected Essays of Richard M. Stallman, 129-131. Boston: Free Software Foundation.

Tavani, Herman T. 2008. Informational Privacy: Concepts, Theories, and Controversies. In The Handbook of Information and Computer Ethics, edited by Kenneth Einar Himma and Herman T. Tavani, 131-164. Hoboken: Wiley.

Varian, Hal R. 1997. Economic Aspects of Personal Privacy. In Privacy and Self-regulation in the Information Age, edited by National Telecommunications and Information Administration (NTIA). Washington: NTIA.

Wacks, Raymond. 2010. Privacy. A Very Short Introduction. Oxford: Oxford University Press.

Warren, Samuel and Louis Brandeis. 1890. The Right to Privacy. In Philosophical Dimensions of Privacy: An Anthology, edited by Ferdinand Schoeman, 75-103. Cambridge: Cambridge University Press.

Westin, Alan. 1967. Privacy and Freedom. New York: Atheneum.

Wolf, Marty. J., Keith W. Miller, and Frances S. Grodzinsky. 2009. On the Meaning of Free Software. Ethics and Information Technology 11 (4): 279-286.

Wong, Phil. 2010. Conversations About the Internet \#5: Anonymous Facebook Employee. Accessed February 25, 2012. http://therumpus.net/2010/01/conversations-about-the-internet-5-anonymous-facebook-employee/3/

Žižek, Slavoj, ed. 1995. Mapping Ideology. London: Verso.

\section{About the Author}

Sebastian Sevignani

studied media and communication, philosophy, and theology at the University of Salzburg. He obtained a master's degree in communication studies in 2009. From 2007 until 2010, he worked at the University of Salzburg's Department of Communication Studies as a scholar in the Media Economics Research Group. He has started working on his doctoral thesis, which focuses on the problem of privacy in (informational) capitalism. Sebastian is a member of the Unified Theory of Information Research Group (UTI) and of the working group "Public Policy and the Regulation of Surveillance" of the European Cooperation in Science and Technology Action "Living in Surveillance Societies (COST Action IS0807)". He is a member of the editorial team of tripleC: Journal for a Global Sustainable Information Society. 